\title{
Seasonal migration, vertical activity, and winter temperature experience of Greenland halibut Reinhardtius hippoglossoides in West Greenland waters
}

\author{
Jesper Boje ${ }^{1}$, Stefan Neuenfeldtt ${ }^{1}$, Claus Reedtz Sparrevohn ${ }^{2}$, Ole Eigaard ${ }^{1}$, \\ Jane W. Behrens ${ }^{1, *}$
}

${ }^{1}$ Technical University of Denmark, National Institute of Aquatic Resources, Kavalergaarden 6, 2920 Charlottenlund, Denmark

${ }^{2}$ Danish Pelagic Producers Organization, HC Andersens Boulevard 37, 1553 Copenhagen, Denmark

\begin{abstract}
The deep-water flatfish Greenland halibut Reinhardtius hippoglossoides (Walbaum) is common along the West Greenland coast. In the northwestern fjords, Greenland halibut is an important socio-economic resource for the Greenland community, but due to the deep and partly ice-covered environment, very little is known about its behavior and habitat characteristics. We tagged adult Greenland halibut in the waters off Ilulissat with electronic data storage tags that collected information on depth, temperature, and time. Although clear differences between individuals in migration and vertical behavior were present, we discovered a consistent seasonal migration from the relatively shallow-water Disko Bay area into the deep waters of the Ilulissat Icefjord, where the fish resided in the winter months before returning to Disko Bay. Vertical activity was pronounced at both locations, with fish covering vertical distances of up to $100 \mathrm{~m}$ within 15 min. During the winter months, the fish experienced temperatures between ca. 0 and $4^{\circ} \mathrm{C}$, with most experiencing temperatures of 2 to $3^{\circ} \mathrm{C}$. Irrespective of year and quarter of the year, the fish experienced warmer water and a broader range of temperatures when resident in Disko Bay (mean range $2.6^{\circ} \mathrm{C}$ ) than when resident in the ice fjord (mean range $1.4^{\circ} \mathrm{C}$ ). Using the tagged halibut as a 'live tool,' we show that parts of the ice fjord are hundreds of meters deeper than previously thought. We also document the first seawater temperature measurements made beneath the Jakobshavn Isbræ outlet glacier, revealing a positive relationship between depth and temperature for the upper $600 \mathrm{~m}$ and a between-year variation in temperatures beneath the ice sheet in 2001, 2002, and 2003.
\end{abstract}

KEY WORDS: Archival tags · Arctic $\cdot$ Behavior $\cdot$ Habitat $\cdot$ Seawater temperatures $\cdot$ Swimming speed

\section{INTRODUCTION}

Greenland halibut Reinhardtius hippoglossoides (Walbaum, 1792) is a deepwater flatfish widely distributed throughout the North Atlantic. With its plentiful numbers along the west coast of Greenland, this species has provided a socio-economically important resource for the Greenlandic people for more than a century. This traditional fishery developed-and is centered in-a small area off Ilulissat and the more northerly Torssukateq icefjord (Disko Bay), where approximately 8000-9000 t are caught annually, with a historic high of about $13000 \mathrm{t}$ in 2004 . The fishery is mostly longlines and gill nets from small open boats and cutters (Smidt 1969, Nygaard \& Boje 2013). Overall, this very concentrated fishery is of vital importance to the Greenland community. Furthermore, the Ilulissat Icefjord is a UNESCO World Heritage site that requires special considerations for the management of its wildlife and unique community. 
Greenland halibut in the fjords of West Greenland are thought to be recruited from the Davis Strait stock that also provides recruits to the eastern Canada-West Greenland stock complex. However, the adults appear resident in the fjords (i.e. isolated from the spawning stock; Boje 2002) but with only few females observed in late maturing condition. The Disko Bay area presumably serves as a transition area for immature and adolescent individuals during their movement towards the deeper parts and inner fjords in Disko Bay (Riget \& Boje 1987, Morgan et al. 2003, Gundersen et al. 2013).

More than $40 \mathrm{yr}$ of anecdotal information (de Groot 1970), assumptions, and indirect evidence (e.g. on feeding habits; Jørgensen 1997, Solmundsson 2007) suggest that Greenland halibut use the pelagic environment. Advances within the last couple of decades in the deployment of data storage tags (DSTs) have made possible direct observations of behavior and assessments of habitat occupancy under natural conditions. By combining information from individual DST-based depth trajectories with recordings of body angles from pitch and roll DSTs, Vollen \& Albert (2008) and Albert et al. (2011) documented both extensive vertical activity of Greenland halibut along the continental slope between Norway and Spitsbergen and use of the pelagic environment for up to one-fourth of an individual's time.

Current stock assessments of Greenland halibut in West Greenland waters are based on data mainly from bottom gears, such as longlines, gill nets, and trawls (Bowering \& Nedreaas 2000). Such monitoring schemes will be sensitive to temporal variation in how Greenland halibut use the pelagic zone. Therefore, identifying and quantifying seasonal and vertical migrations are important in order to obtain reliable biomass estimates. Little is known about the behavior and associated distribution of Greenland halibut in the Disko Bay area; thus, an understanding of the spatial and temporal variation in both horizontal migration and vertical activity patterns will improve the knowledge base to promote sustainable management of the fishery.

Information on how environmental parameters (e.g. temperature) relate to distributional patterns of Greenland halibut is essential for management and conservation (Schick et al. 2008), but also because an increase in temperature and reduction in sea ice has occurred in polar regions over the past 2 decades (Serreze et al. 2000, Rayner et al. 2003, Holland et al. 2008, Hansen et al. 2012) and is expected to continue. As a species, Greenland halibut are found in habitats with temperatures ranging mainly between
0 and $6^{\circ} \mathrm{C}$ (although sporadic occurrences have been recorded at subzero temperatures and at temperatures $\geq 6^{\circ} \mathrm{C}$; Bowering \& Nedreaas 2000), but on a regional scale, the temperature experience is likely defined by the available environment, e.g. in the Cumberland Sound, in which the fish encounter temperatures from 1.3 to $2.7^{\circ} \mathrm{C}$ (Peklova et al. 2012). Presently no information is available on the thermal history of Greenland halibut in West Greenland waters.

In order to identify potential migrations and investigate vertical swimming activity and thermal experience, specimens were tagged with DSTs (recording pressure and temperature) within a small fishing area off Ilulissat. The Greenland halibut population inhabiting the Disko Bay area is considered to be resident (i.e. it does not return to Davis Strait to spawn) and is exposed to an intensive commercial fishery. Together this provides an ideal setting for potentially high tag recovery rates.

\section{MATERIALS AND METHODS}

\section{Regional bathymetry}

The bathymetry of Disko Bay, near the town of Ilulissat, plateaus with an average depth of 300 to $400 \mathrm{~m}$. A submarine sill at the mouth of the Ilulissat Icefjord separates the Disko Bay area from the icefjord, with the sill's deepest point being at $250 \mathrm{~m}$ depth (see Fig. 2; Schumann et al. 2012). The Jakobshavn Isbrae outlet glacier (i.e. the ice sheet that emerges in the Ilulissat Icefjord) covers the fjord with icebergs and brash sea ice year-round, such that this area is not easily accessible for surveying. However, Holland et al. (2008) conducted research in the area and suggested that depths are almost uniform at $800 \mathrm{~m}$.

\section{Study site and tagging}

On 3 occasions (September/October 2001, 2002, and 2003), a total of 210 Greenland halibut were tagged in the waters off Ilulissat in West Greenland (Fig. 1) with electronic tags (DST milli, Star-Oddi). The tags $(12.5 \times 38.4 \mathrm{~mm}$ and a weight of $10 \mathrm{~g}$ in air, $5 \mathrm{~g}$ in water) had a 24 mo battery life and memory capacity of 21738 recordings. The tags were programmed to record time, pressure (depth), and temperature every 10,15 , or $60 \mathrm{~min}$ within the ranges -1 to $+40^{\circ} \mathrm{C}$ and 0.5 to $900 \mathrm{~m}$. Tagging was conducted from small open vessels fishing with longlines. The longlines were hauled manually at a speed 


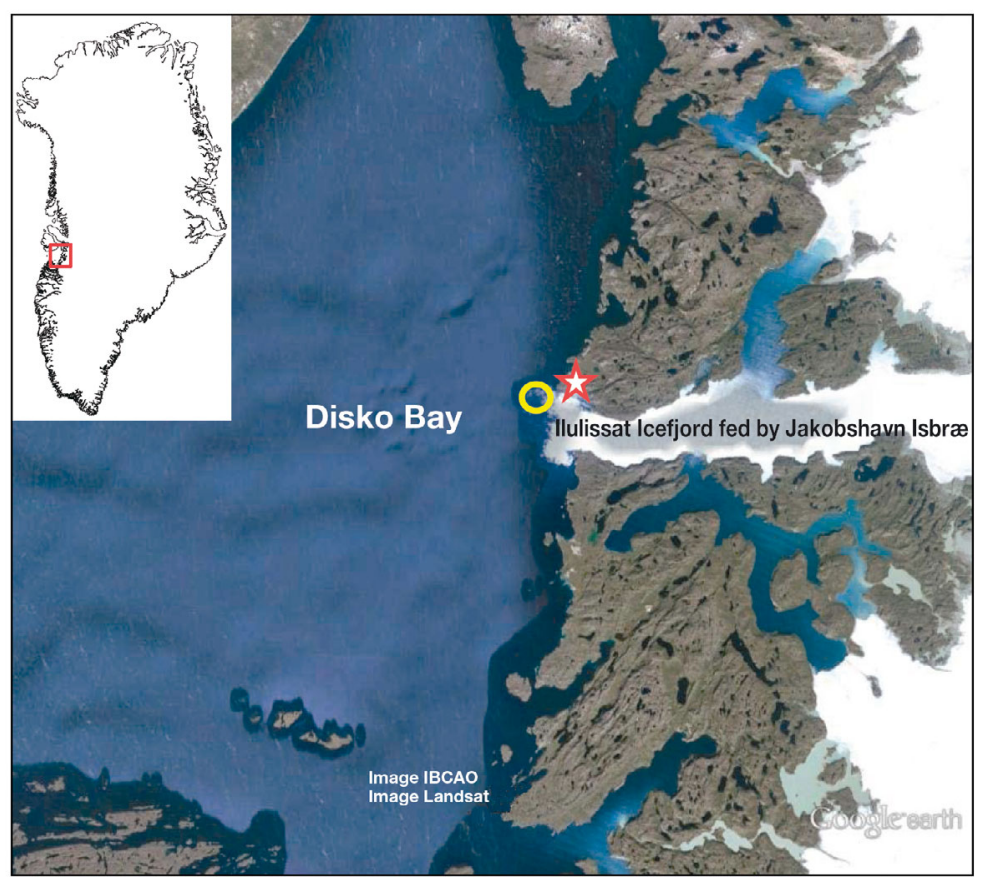

Fig. 1. Study area (Disko Bay and the Ilulissat Icefjord) in Greenland and tagging site (yellow circle) off the town of Ilulissat (red star)

of 1 to $2 \mathrm{~h} \operatorname{line}^{-1}$ (ca. 200 hooks at depths of 300$500 \mathrm{~m}$ ), and the hooks were gently removed from captured fish. Only fish hooked in the mouth region were selected for tagging in order to ensure high survival rates. Furthermore, the condition of the fish was judged visually, mainly by examining the color of the gills, to inspect for internal hooking injuries, and only fish in apparent good shape were measured for total length (referred to hereafter as body length, BL) and tagged. The DST was fixed externally close to and below the dorsal fin by means of 2 titanium wires, whereafter the fish was immediately released. Only large fish (BL: $42-93 \mathrm{~cm}$, mean $\pm \mathrm{SD}: 59 \pm 7.3 \mathrm{~cm}$ ) were tagged to ensure high probability of recapture in the commercial fishery.

\section{Data analysis}

In order to eliminate potentially artificial behavior patterns caused by the tagging procedure and to prevent inclusion of faulty temperature and depth recordings, the first $4 \mathrm{~d}$ of data were removed from each record. Individual depth records over time were plotted using all data from the retrieved DSTs. When plot- ting individual fish depth records, a running mean, running maximum, and running minimum were calculated using a $24 \mathrm{~h}$ window. Maximum swimming speed was determined based on the combined data from all fish; however, fish with sampling intervals of 60 min (ID 3 and 4) were excluded from further analysis. Information of year to year variation in temperature in relation to depth was obtained by first splitting individual depth trajectories into periods, where fish could be assigned to either Disko Bay or the icefjord using the bathymetry of each area (Fig. 2, also see Discussion below). Data from fish with ID numbers 2, 5, and 8 (see Table 1) were used for the individual frequency distribution of depth changes inside the icefjord and in Disko Bay, as these fish had sufficient data for both locations to make a comparison possible. A smaller number of observations were assigned to a transition area because the depth information could not be interpreted unambiguously. Following this assignment of individual observations to area, data were pooled for the years 2001 to 2003 and plotted separately for Disko Bay and the icefjord.

\section{RESULTS}

Thirteen tagged Greenland halibut were recaptured by the end of 2012, with time records varying from 69 to $176 \mathrm{~d}$. Data from one tag were faulty (not shown) and were not used for analysis. Details on the

Table 1. Overview of biological and data storage tag (DST) information for Greenland halibut Reinhardtius hippoglossoides tagged in the waters off Ilulissat, west Greenland. Body length (BL) was measured during tagging

\begin{tabular}{|lcccccr|}
\hline $\begin{array}{l}\text { Fish } \\
\text { ID }\end{array}$ & $\begin{array}{c}\text { BL } \\
(\mathrm{cm})\end{array}$ & $\begin{array}{c}\text { Release } \\
\text { date }\end{array}$ & $\begin{array}{c}\text { Recapture } \\
\text { date }\end{array}$ & $\begin{array}{c}\text { No. of } \\
\text { days } \\
\text { recording }\end{array}$ & $\begin{array}{c}\text { Sampling } \\
\text { interval } \\
(\mathrm{min})\end{array}$ & $\begin{array}{r}\text { No. of } \\
\text { obser- } \\
\text { vations }\end{array}$ \\
\hline 1 & 58 & 7 Oct 03 & 25 Jan 04 & 110 & 10 & 15840 \\
2 & 66 & 17 Sep 02 & 25 Feb 03 & 161 & 15 & 15456 \\
3 & 59 & 17 Sep 02 & 27 Feb 03 & 163 & 60 & 3912 \\
4 & 47 & 17 Sep 02 & 12 Mar 03 & 176 & 60 & 4224 \\
5 & 58 & 16 Sep 02 & 6 Mar 03 & 171 & 15 & 16416 \\
6 & 60 & 18 Sep 02 & 7 Dec 02 & 80 & 15 & 7680 \\
7 & 54 & 17 Sep 02 & 25 Jan 03 & 130 & 15 & 12480 \\
8 & 63 & 17 Sep 02 & 3 Mar 03 & 167 & 15 & 16032 \\
9 & 62 & 17 Sep 02 & 12 Feb 03 & 148 & 15 & 14208 \\
10 & 55 & 17 Sep 02 & 25 Nov 02 & 69 & 15 & 6624 \\
11 & 65 & 17 Sep 02 & 25 Nov 02 & 69 & 15 & 6624 \\
12 & 62 & 15 Sep 01 & 4 Jan 02 & 111 & $10 / 60$ & 15984 \\
\hline
\end{tabular}




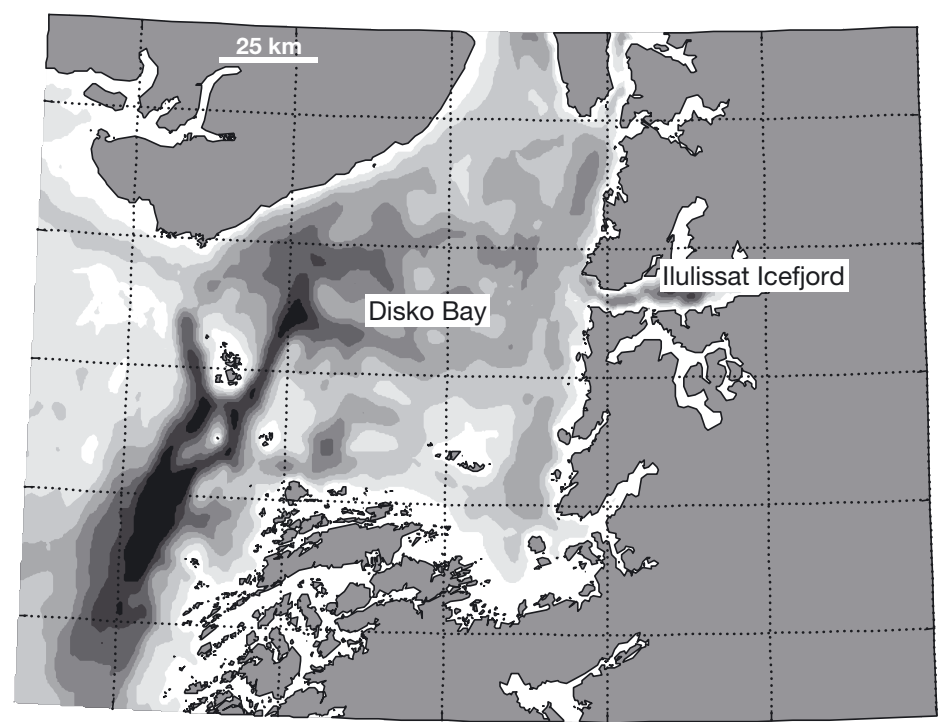

Depth $(m)$

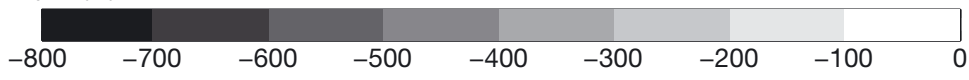

Fig. 2. Bathymetry of the study area (Disco Bay and Ilulissat Icefjord), including the Inner Egedesminde Deep to the west where depths reach about $800 \mathrm{~m}$. Map adapted from C. Gladish et al. (unpubl.)

remaining 12 recovered tags are provided in Table 1. Three fish were recaptured deep inside the icefjord (fish with ID numbers 3,6, and 10), 3 at the mouth of the icefjord (ID 4, 5, and 8), and 4 just east of it or along the northern coastline (ID 1, 2, 7, and 9), whereas the recapture sites for the 2 remaining fish (ID 11 and 12) were not known (Fig. 3).

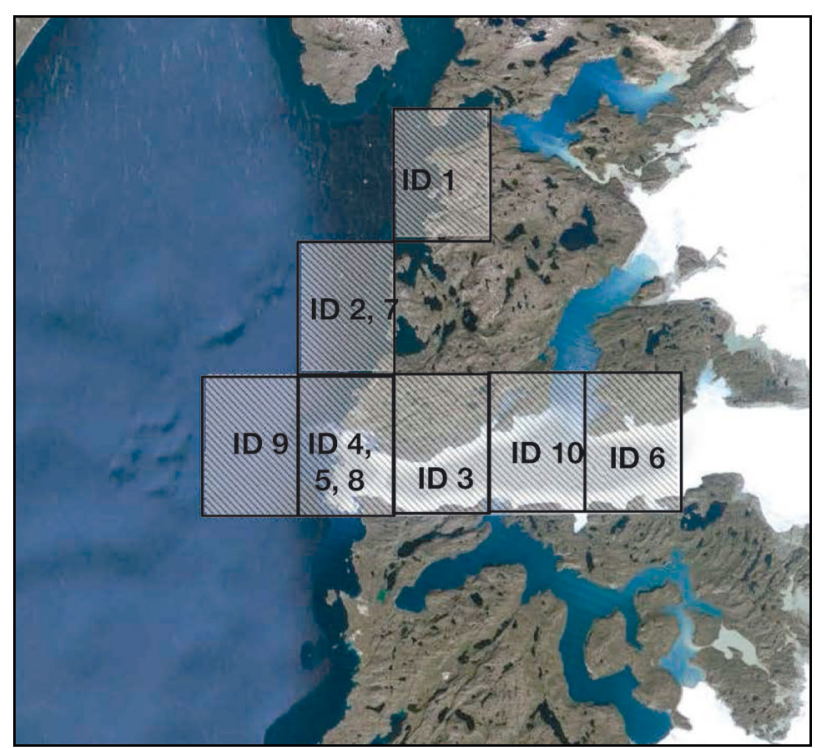

Fig. 3. Statistical squares within which tagged Greenland halibut Reinhardtius hippoglossoides were recaptured, as indicated by fish ID numbers (see Table 1). Recapture locations were available for 10 of the 12 recaptured fish

\section{Local seasonal migrations}

From the month of release (September) to November, Greenland halibut changed their mean depth from 350 to $625 \mathrm{~m}$ and stayed at this maximal mean depth within the icefjord throughout December. However, from December to January, fish initiated movements towards shallower water and by February had entered the relatively shallow Disko Bay water, residing at depths of $300 \mathrm{~m}$ on average (Fig. 4).

\section{Initiation of individual seasonal migration into the Ilulissat icefjord}

The depth trajectories revealed differences in migration timing between individuals. Seven individuals (ID 1, 3, 5, 6, 8, $9,11)$ entered the icefjord within a few days following tagging in the waters just off Ilulissat, as evident from the initial steep depth gradients going from shallow

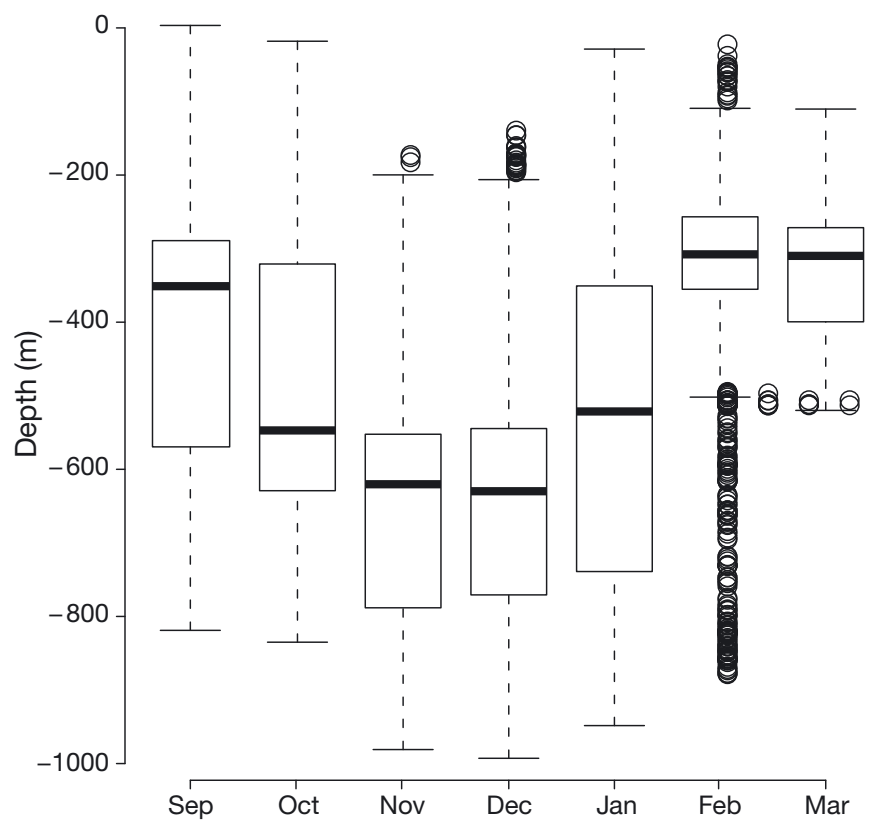

Fig. 4. Depth by month for Greenland halibut Reinhardtius hippoglossoides undertaking seasonal migrations into the Ilulissat Icefjord in September-October and back to shallower waters of Disko Bay in February-March. Solid line is the median, box is the interquartile area (bottom and top are 25th and 75th percentiles, respectively). Whiskers show either the $\mathrm{max} / \mathrm{min}$ observation if within 1.5 of the interquartile range or 1.5 times the interquartile range. Circles are observations (outliers) not covered in the area between the whiskers 
(300-400 m) to deep (600-800 m) water (example shown in Fig. 5A). The remaining 5 fish (ID 2, 4, 7, 10, 12) stayed in shallow Disko Bay water between 15 and $50 \mathrm{~d}$ before migrating into the icefjord (Fig. 5B). Thus, local migrations into the icefjord seem to occur over a period of 1 to 2 mo during late autumn/early winter. All but 1 of the 7 fish, for which recordings continued into the following year, had left the icefjord sometime between mid-January and mid-February, to take residency in the relatively shallower water of Disko Bay. The exception (ID 4) still resided at approx. $700 \mathrm{~m}$ at time of capture in the icefjord by March.

Distinctive plateaus of approximately $800 \mathrm{~m}$ depths were evident for all fish during their period within the icefjord (examples in Figs. 5 \& 6). Depth trajectories of 2 fish revealed that they occupied the seafloor at 950-1000 m (Fig. 7), although these readings are beyond the depths calibrated for the DSTs.

\section{Vertical activity and vertical swimming speeds}

All recaptured tags revealed alternating periods of distinctly different vertical activity, periods that were apparent on both large (months) and small (days and hours) scales (Fig. 6). For example, between periods with nearly no vertical activity, a fish suddenly ascended from about $800 \mathrm{~m}$ depth to cover more than 250 vertical meters within $1 \mathrm{~h}$, with a maximum distance of $100 \mathrm{~m}$ covered within 15 min (Fig. 6, lower left panel). This equals a maximal vertical swimming speed of about $11 \mathrm{~cm} \mathrm{~s}^{-1}$ or ca. $0.2 \mathrm{BL} \mathrm{s}^{-1}(\mathrm{BL}=58 \mathrm{~cm})$. The fish subsequently returned to $800 \mathrm{~m}$; the descent took $60 \mathrm{~min}$, of which $45 \mathrm{~min}$ were at speeds comparable to the ascent. Maximal vertical swimming speeds ranged between 0.3 and $0.5 \mathrm{BL} \mathrm{s}^{-1}$ with a mean $\pm \mathrm{SD}$ of $0.3 \pm 0.1 \mathrm{BL} \mathrm{s}^{-1}$. In general, however, fish rarely exceeded vertical swimming speeds of $0.1 \mathrm{BL} \mathrm{s}^{-1}$.

Vertical activity was most pronounced when Greenland halibut resided within the icefjord, i.e. vertical movements of up to $\pm 50 \mathrm{~m}$ dominated in Disko Bay (Fig. 8, lower panels), whereas in the icefjord fish undertook longer ascents and descents (Fig. 8, upper panels); 1 fish even covered a vertical distance of approximately $140 \mathrm{~m}$ within $15 \mathrm{~min}$ (Fig. 8, upper panel, middle).

\section{Temperature experience}

Across both locations, Greenland halibut experienced winter temperatures ranging from ca. $0^{\circ} \mathrm{C}$ to an upper limit of $4.2^{\circ} \mathrm{C}$ (see Table 3), with the temperature range for most individual fish being $2-3^{\circ} \mathrm{C}$ (Table 2). The mean thermal experience of fish in the 2 localities differed by $0.5^{\circ} \mathrm{C}$, i.e. $2.8^{\circ} \mathrm{C}$ and $2.3^{\circ} \mathrm{C}$ in Disko Bay and the icefjord, respectively (Table 2). Overall, fish experienced a broader range of temperatures in Disko Bay (mean range $2.6^{\circ} \mathrm{C}$ ) compared to the icefjord (mean range $1.4^{\circ} \mathrm{C}_{i}$ Table 2). Mean monthly temperatures experienced varied between 2.3 and $3.0^{\circ} \mathrm{C}$, the coldest months being November and December, when the fish resided in deep waters inside the icefjord. When comparing
Fig. 5. Individual depth trajectories showing examples of Greenland halibut Reinhardtius hippoglossoides (A) entering the deep waters of the Ilulissat Icefjord immediately after tagging (fish with ID number 5 in Table 1) and (B) staying in the shallower Disko Bay water for an extended period of time (here approximately $1 \mathrm{mo}$ ) before migrating into the icefjord (fish ID 10 in Table 1). The fish in (B) was recaptured by longline within the icefjord on 25 November. Circles are data storage tag (DST) depth observations; black, blue, and red lines are running mean, minimum, and maximum depths, respectively, calculated using a $24 \mathrm{~h}$ window

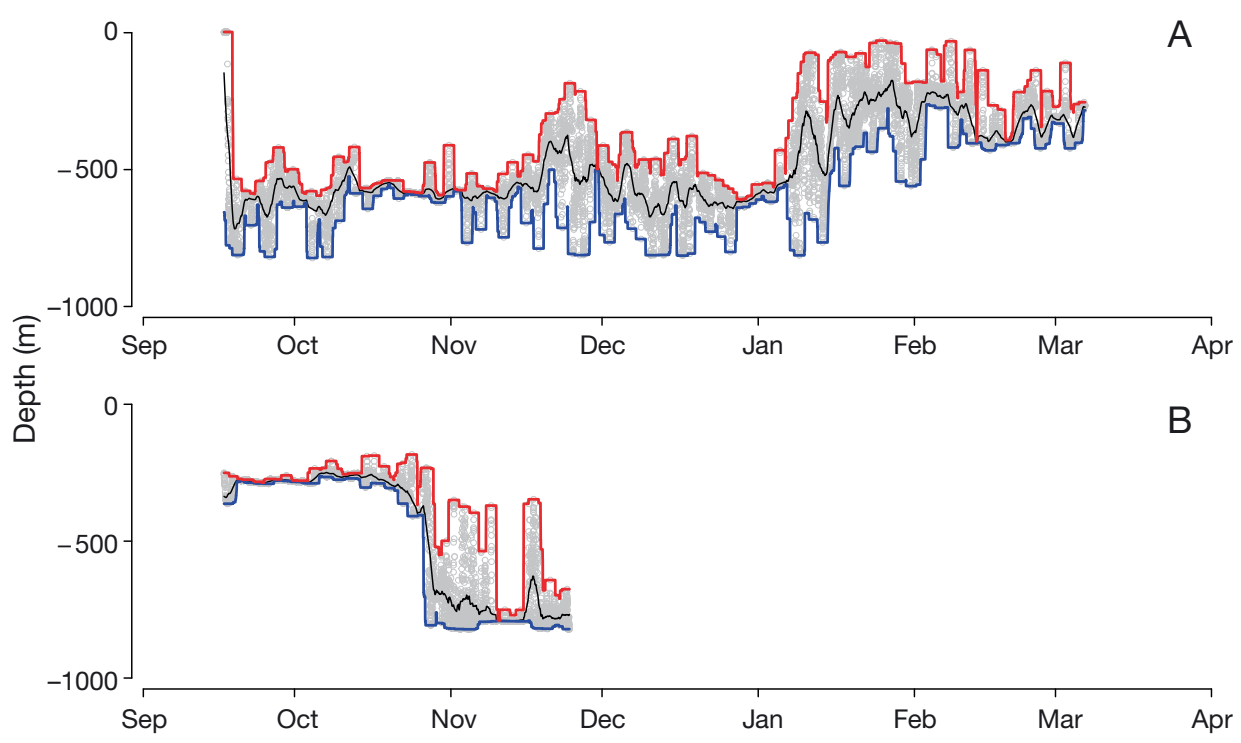



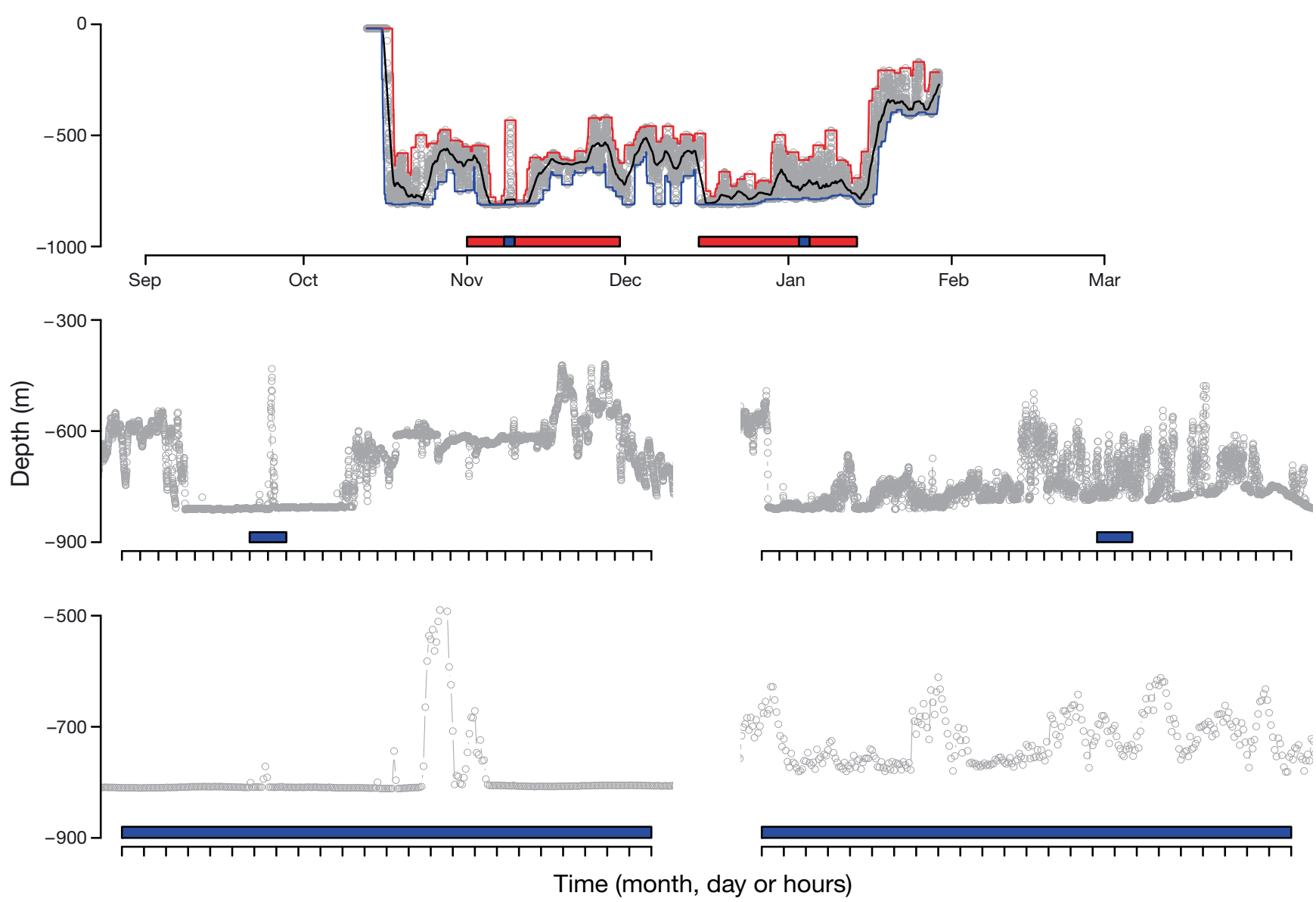

Fig. 6. Example of an individual Greenland halibut Reinhardtius hippoglossoides depth trajectory (fish ID number 1 in Table 1). The fish was released on 7 October and recaptured on 25 January and revealed alternating periods of distinctly different vertical activity, apparent both at large (months, upper graph) and small (days and hours in middle and lower graphs, respectively) scales. Circles are data storage tag (DST) depth observations; black, blue, and red lines are running mean, minimum, and maximum depths, respectively, calculated using a $24 \mathrm{~h}$ window. The ranges of the red horizontal bar in upper graph correspond to the $x$-axes in middle graphs, at the left and the right side, respectively; the range of the blue horizontal bar in the middle graphs correspond to the $x$-axes in the lower graphs

quarterly temperatures in specific years, thermal experience was always highest (by $0.5-0.7^{\circ} \mathrm{C}$ ) when fish resided in Disko Bay as compared to inside the icefjord, whereas there was no quarterly difference in Disko Bay temperatures (Table 3, Fig. 9). Combining all temperature data revealed an increase in temperature at increasing depth for both locations; however, the increase leveled off within the icefjord at depths exceeding approximately $600 \mathrm{~m}$. Overall, temperatures at specific depths were lowest within the icefjord (Fig. 9). Furthermore, when comparing between the same quarters of the year, there was a difference in icefjord temperatures (both mean and depth-specific) between 2001，2002, and 2003. A similar but less distinct trend was evident for the first quarter of the year in Disko Bay. A lack of data prevented comparison in other quarters in this area (Fig. 9, Table 3).

\section{DISCUSSION}

\section{Seasonality of local migrations and depth verifications}

Our data revealed a strong seasonality in local migrations with migrations into the icefjord occurring in September and October (Fig. 4). The tagged fish subsequently resided in the deep waters of the icefjord for periods of more than 3 mo. Since information from DSTs does not provide the option of direct geolocation, our interpretation of location of the tagged fish is based on correlations between measured depths, previous reports on regional-scale bathymetry, and recapture sites. Depth conditions and contours are well described within the Disko Bay area. The shallowest part, extending from the mouth of the icefjord and plateauing to the south-west of Disko 


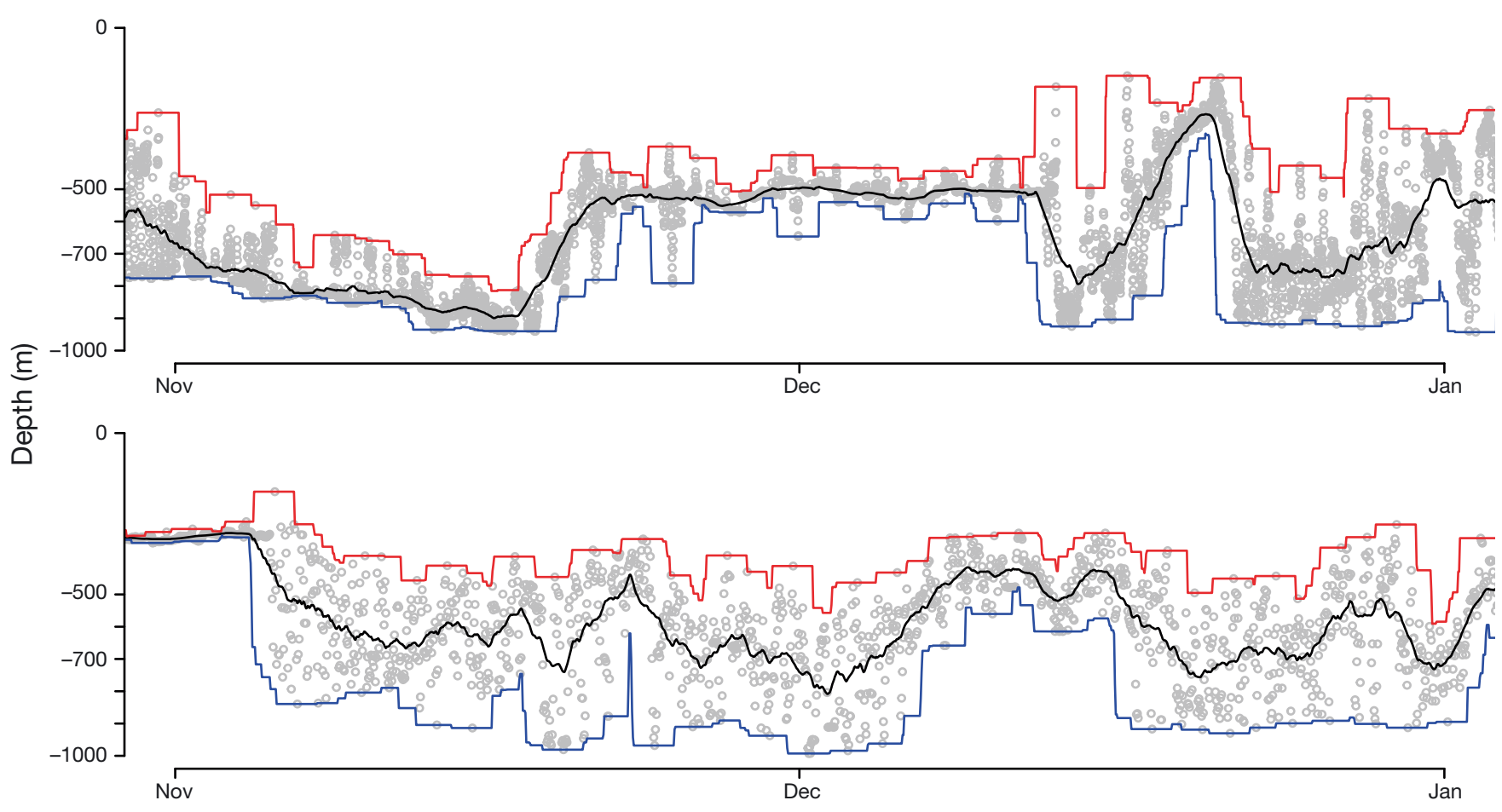

Fig. 7. Individual depth trajectories from 2 tagged Greenland halibut Reinhardtius hippoglossoides (fish ID numbers 7 and 4 , upper and lower panels, respectively, see Table 1) for November to January, revealing that the fish entered waters of 900-950 m depth inside the Ilulissat Icefjord. Black, blue, and red lines are running means, minimum, and maximum depths, respectively

Island, is between 100 and $400 \mathrm{~m}$, whereas the icefjord is substantially deeper at $800 \mathrm{~m}$ (Buch 1990, Holland et al. 2008, Hansen et al. 2012, Schumann et al. 2012). Deep-water depth records could in theory have resulted from fish visiting the 800 to $1000 \mathrm{~m}$

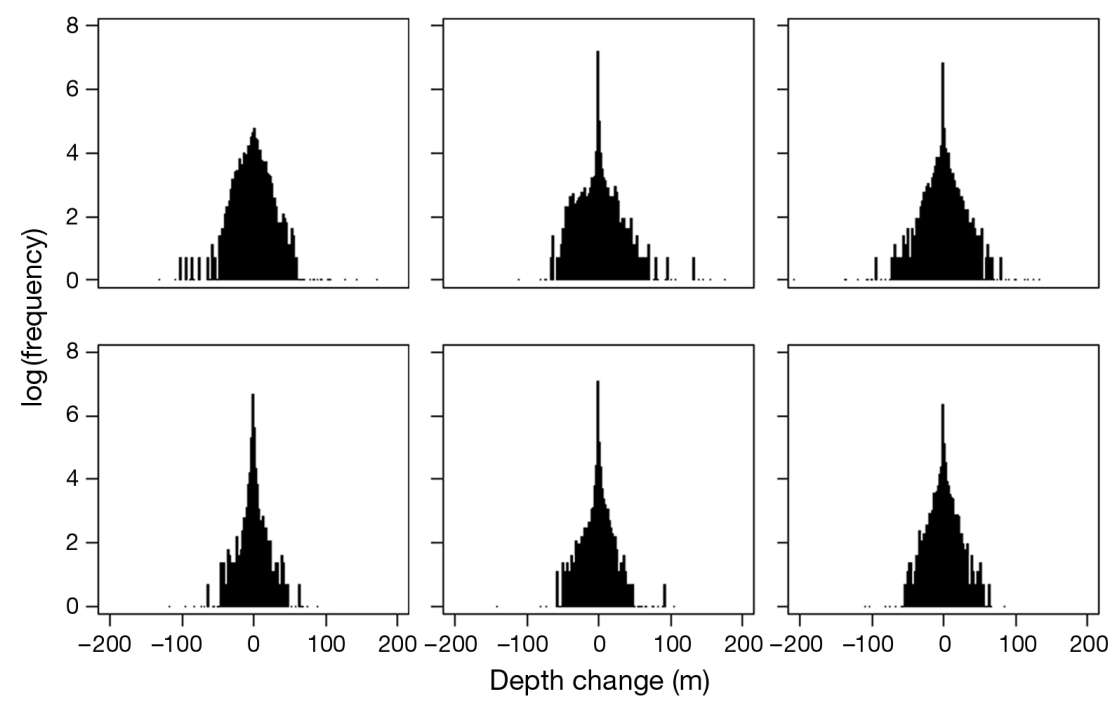

Fig. 8. Log-transformed frequencies of depth changes between adjacent observations. Left, middle, and right panel are Greenland halibut Reinhardtius hippoglossoides with ID numbers 2, 5, and 8, respectively (see Table 1). Observations inside the Ilulissat Icefjord are shown in the upper panels, and observations inside Disko Bay are shown in the lower panels deep waters of the more south-eastern Inner Egedesminde Deep, a trough cutting across the continental shelf from the shelf break and into Disko Bay (Weidick \& Bennike 2007, Holland et al. 2008, Hansen et al. 2012). However, 3 facts speak against this; firstly, the straight-line distance to Inner Egedesminde Dyb is around $100 \mathrm{~km}$ and is considerably longer in 'true' swimming distance, considering the topography and that fish do not swim in a straight line; secondly, 2 fish were recaptured at depths of approx. $800 \mathrm{~m}$ in the icefjord and 8 additional fish were recaptured within statistical squares (Greenlandic measure) either inside or at the mouth of the icefjord or along the northward running coast (Fig. 3); and, finally, all depth profiles (including profiles from the 2 fish recaptured inside the icefjord) showed a steep gradient when fish moved into deep waters (examples in Figs. 5-7), indicating entrance into the icefjord. According to the regional bathymetry (Fig. 2), a gradual decrease in depth would have been expected if fish had swum towards the deeper Inner 
Egedesminde Deep. We are thus confident that fish experiencing depths greater than around $500 \mathrm{~m}$ reside in the icefjord. Results from traditional t-bar tagging of Greenland halibut between 1986 and 1998 (7244 fish tagged in total) revealed high site fidelity and very limited long-distance migration of fish in northwestern fjords (Boje 2002).

Due to the permanent ice cover that impedes accessibility, the icefjord is poorly investigated and the only previous bathymetric report of the area suggests it to be of an almost uniform depth of $800 \mathrm{~m}$ (Holland et al. 2008). Our data reconfirm this, as individual maximum
Table 2. Temperature experience of individual Greenland halibut Reinhardtius hippoglossoides at 2 different locations. Mean thermal range was $2.6^{\circ} \mathrm{C}$ in Disko Bay and $1.4^{\circ} \mathrm{C}$ in the icefjord. BL: body length

\begin{tabular}{|c|c|c|c|c|c|c|c|c|}
\hline \multirow{2}{*}{$\begin{array}{l}\text { Fish } \\
\text { ID }\end{array}$} & \multicolumn{4}{|c|}{ Disko Bay temperature $\left({ }^{\circ} \mathrm{C}\right)$} & \multicolumn{4}{|c|}{ Icefjord temperature $\left({ }^{\circ} \mathrm{C}\right)$} \\
\hline & No. of days & Min & Max & Mean & No. of days & Min & Max & Mean \\
\hline 1 & 11 & 1.1 & 3.0 & 2.5 & 93 & 1.5 & 2.7 & 2.2 \\
\hline 2 & 55 & 1.2 & 3.2 & 3.0 & 106 & 1.0 & 3.1 & 2.4 \\
\hline 3 & & & & & 164 & 1.3 & 2.7 & 2.4 \\
\hline 4 & 47 & 1.3 & 4.2 & 3.8 & 95 & 0.6 & 2.6 & 2.3 \\
\hline 5 & 34 & -0.1 & 3.2 & 2.7 & 116 & 0.6 & 2.8 & 2.3 \\
\hline 6 & & & & & 78 & 1.6 & 2.6 & 2.3 \\
\hline 7 & 24 & 0.9 & 3.1 & 2.7 & 103 & 1.0 & 2.7 & 2.4 \\
\hline 8 & 44 & 0.6 & 3.2 & 2.8 & 120 & 1.1 & 3.0 & 2.4 \\
\hline 9 & 35 & -0.1 & 2.7 & 2.2 & 110 & 2.2 & 2.5 & 2.3 \\
\hline 10 & 38 & 1.1 & 3.2 & 2.8 & 28 & 1.8 & 2.5 & 2.4 \\
\hline \multirow[t]{2}{*}{11} & & & & & 49 & 1.8 & 2.6 & 2.3 \\
\hline & \multicolumn{3}{|c|}{$\begin{array}{l}\text { Average of mean } \\
\text { temperatures: }\end{array}$} & 2.8 & \multicolumn{3}{|c|}{$\begin{array}{l}\text { Average of mean : } \\
\text { temperatures }\end{array}$} & 2.3 \\
\hline
\end{tabular}
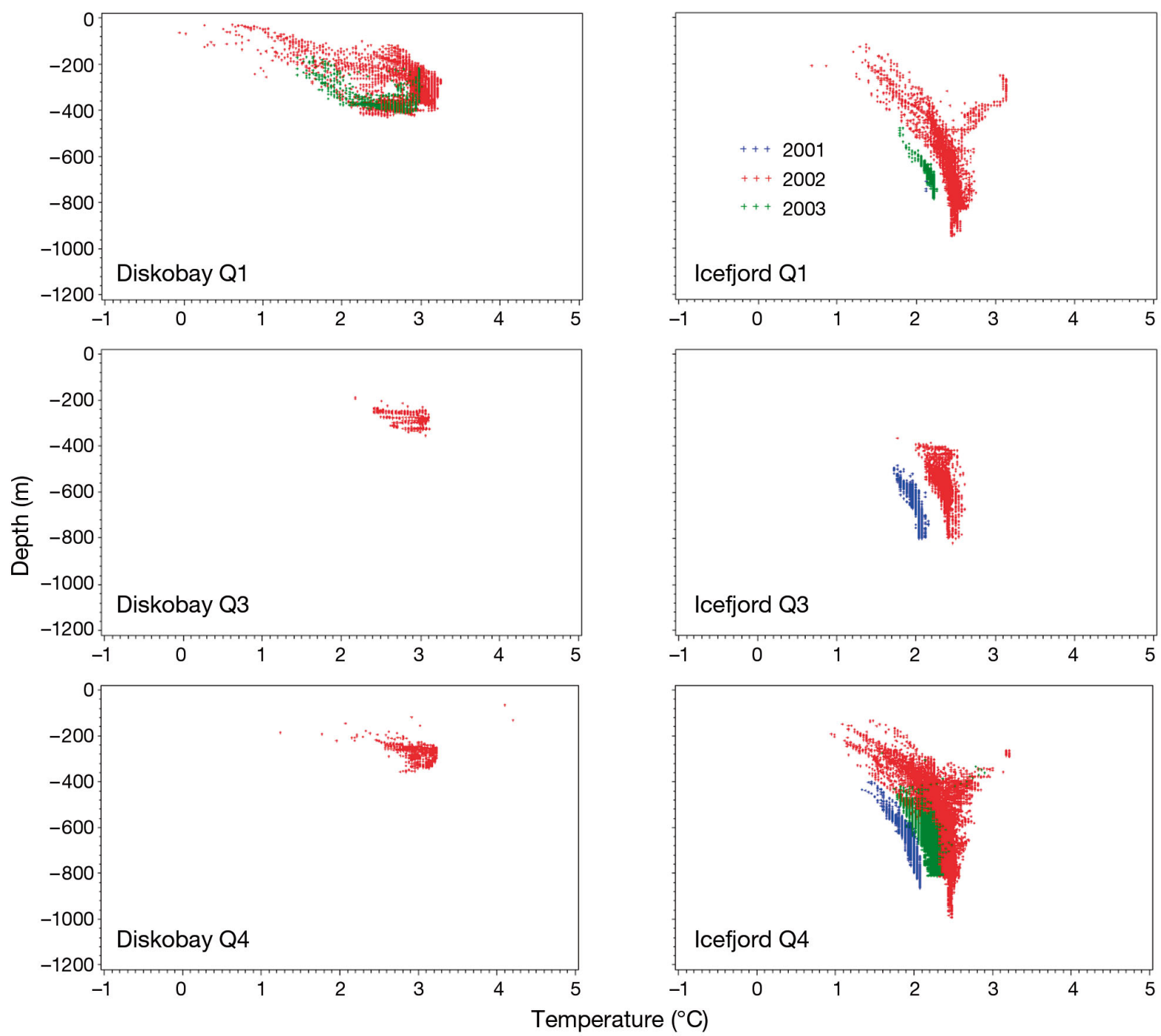

Fig. 9. Pooled data from all Greenland halibut Reinhardtius hippoglossoides showing quarterly temperature experiences of the fish in relation to depth, area, and year. Q1 (Q3, Q4): first (third, fourth) quarter 
Table 3. Data storage tag (DST)-derived pooled temperature measurements as related to area, quarter of the year, and year. DB: Disko Bay; IF: icefjord

\begin{tabular}{|lccccccc|}
\hline \multirow{2}{*}{ Area } & Quarter & \multirow{2}{*}{ Year } & \multirow{2}{*}{ No. of } & \multicolumn{4}{c|}{ Temperature $\left({ }^{\circ} \mathrm{C}\right)$} \\
& & & obs. & Mean & SD & Min & Max \\
\hline DB & 1 & 2002 & 9051 & 2.9 & 0.3 & -0.1 & 3.3 \\
DB & 1 & 2003 & 1243 & 2.6 & 0.3 & 1.4 & 3.0 \\
DB & 3 & 2002 & 2661 & 2.9 & 0.2 & 2.2 & 3.1 \\
DB & 4 & 2002 & 3120 & 3.0 & 0.2 & 1.2 & 4.2 \\
IF & 1 & 2001 & 4 & 2.1 & 0.0 & 2.1 & 2.2 \\
IF & 1 & 2002 & 7793 & 2.4 & 0.2 & 0.7 & 3.1 \\
IF & 1 & 2003 & 1584 & 2.2 & 0.1 & 1.8 & 2.2 \\
IF & 3 & 2001 & 2141 & 2.0 & 0.1 & 1.7 & 2.2 \\
IF & 3 & 2002 & 4640 & 2.3 & 0.1 & 1.8 & 2.6 \\
IF & 4 & 2001 & 7600 & 2.0 & 0.1 & 1.3 & 2.1 \\
IF & 4 & 2002 & 49867 & 2.3 & 0.2 & 0.9 & 3.2 \\
IF & 4 & 2003 & 10944 & 2.2 & 0.1 & 1.6 & 2.9 \\
\hline
\end{tabular}

depth profiles often plateaued at $800 \mathrm{~m}$ (Fig. 6). However, the fjord is evidently deeper in parts, as 2 of the tagged fish experienced depths of 950-1000 m (Fig. 7). Using fish as measuring tools can thus provide further details under hostile conditions where conventional measuring techniques are difficult or impossible to apply. It should be noted that because we only tagged Greenland halibut in September/ October, and had the latest recapture in March of the subsequent year, our data would not capture the existence of other migration patterns from Disko Bay during spring or summer months.

Migration is expected when the suitability of sites varies in relation to the needs of the individuals. Two obvious needs driving such spatial displacement are spawning and feeding. Since only a few running females have been observed in the Disko Bay area (i.e. no eggs, larvae, or ripe or spent fish of either sex), consensus is that spawning does not occur here to an extent that would serve as a reproductive basis for this population (Riget \& Boje 1987, Morgan et al. 2003). Given the lack of corroborative data such as stomach content analysis or detailed knowledge on migratory patterns of prey, it remains speculative whether Greenland halibut enter the icefjord in September and November to follow their primary prey.

\section{Vertical activity}

The depth trajectories from recaptured tags revealed alternating periods of distinct vertical activity and periods spent at, or in close proximity to, the bottom. Most fish exhibited more vertical activity when within the icefjord as compared to Disko Bay waters (Fig. 8). As demersal swimming along a slope can re- sult in significant changes in depth, a common challenge when analyzing time series of depth distributions of demersal fish living on slopes is to distinguish 'true pelagic distributions' from movements along the sea bed. Even if the present depth records bore no information about the distance from the sea bed, it seems reasonable to assume that part of the high vertical-activity periods showing sudden and highmagnitude changes in depth is associated with pelagic distribution (Godø \& Michalsen 2000, West \& Stevens 2001, Hunter et al. 2003, 2004). Such behavior is probably related to foraging on pelagic prey, and Greenland halibut are often caught with longlines placed in the water column (Nygaard \& Boje 2011, our own observations). Hence vertical activity should be expected to vary according to prey availability, as has been shown for Greenland halibut living along the continental slope between Norway and Spitsbergen. Here both diel and seasonal cycles of pelagic activity of adult fish were related to the presence of pelagic fish prey species (mainly blue whiting Micromesistius poutassou and Atlantic herring Clupea harengus) and various crustaceans (Vollen \& Albert 2008). Other factors may drive vertical activity in flatfish; for example, during periods of migration, southern and central populations of North Sea plaice Pleuronectes platessa (L.) inhabit mid-waters for up to several hours per day to take advantage of tidal streams providing transport opportunity (Metcalfe et al. 2002, Hunter et al. 2003, 2004).

Periods characterized by less activity may serve to facilitate digestion and absorption of food. Gastrointestinal blood flow increases profoundly after intake of a meal (Axelsson \& Fritsche 1991, Behrens et al. 2012), and during less active periods, blood can be redistributed away from the swimming muscles and towards the stomach region, thus enhancing digestive performance. Although purely speculative, this may (at least partly) explain the more quiescent periods. Periods dedicated to digestion have been suggested to cause the rare appearance of clear diel or semi-diel vertical migration patterns in DST-tagged cod Gadus morhua (Godø \& Michalsen 2000).

Two individuals reached the maximal observed vertical swimming speed of $0.5 \mathrm{BL} \mathrm{s}^{-1}$, with the average amongst all fish being $0.3 \mathrm{BL} \mathrm{s}^{-1}$. The maximal vertical speed observed in the present study is higher than that found for Greenland halibut tagged in Cumberland Sound (using the same method) where fish swam a maximum of $12 \mathrm{~cm} \mathrm{~s}^{-1}$ or $0.14 \mathrm{BL} \mathrm{s}^{-1}$, excluding swimming speeds of $0.5 \mathrm{BL} \mathrm{s}^{-1}$ obtained from fish during their initial descent after tagging (which was considered to be unnatural behavior; Peklova et al. 2012). However, the distance traveled will inevitably 
be greater than indicated by the depth change, i.e. vertical swimming speeds are underestimations of actual swimming speeds. Assuming an average pelagic swimming angle of $45^{\circ}$ for Greenland halibut (Albert et al. 2011), actual swimming speeds are on average 0.2-0.3 $\mathrm{BL} \mathrm{s}^{-1}$. Maximal actual swimming speed would be about $1 \mathrm{BL} \mathrm{s}^{-1}$ using a $60^{\circ}$ swimming angle (Albert et al. 2011). This is less than freely swimming Japanese flounder Paralichthys olivaceus, which prefer swimming at $0.6-0.7 \mathrm{BL} \mathrm{s}^{-1}$ (maximally $2.3 \mathrm{BL} \mathrm{s}^{-1}$ ) and rarely exceed 1.2 $\mathrm{BL} \mathrm{s}^{-1}$ (Kawabe et al. $2003,2004)$. Besides 'true' species-specific differences, part of the pronounced difference in swimming performance between the 2 flatfish species may reside in the different methodologies used. Depth records from conventional DSTs provide the net vertical distance within a defined time window set by the sampling frequency (in our case mostly every $15 \mathrm{~min}$ ), and because fish most likely do not swim in a straight line during a 15 min period, this underestimates the true distance traveled; in contrast, accelerometers applied on Japanese flounder provide short-duration, highfrequency acceleration measures (Kawabe et al. 2003, 2004, Broell et al. 2013, Makiguchi et al. 2013).

In European flounder $P$. flesus, lactic acid levels are elevated in swimming muscle at speeds of around $0.5 \mathrm{BL} \mathrm{s}^{-1}$, indicating that an anaerobic component supplements the energy requirements of the swimming muscle (Duthie 1982). The low average swimming speeds found in our study suggest that Greenland halibut operate aerobically most of the time, thus avoiding building up an oxygen deficit that must be replenished during more quiescent periods (Milligan et al. 2000).

The observed vertical behavior of Greenland halibut, at least partly reflecting movements into the pelagic, will inevitably bias the estimated biomass indices that are used to advise managers on stock status and potential yield. Both demersal longline and bottom trawl are presently used as survey gears in the area, and their design and catch operation could potentially provide biomass underestimates if part of the stock is unavailable to the gear. However, since no absolute biomass estimates are derived from the surveys, the problem only occurs if the pelagic behavior is variable over time. With the limited time range of recordings in the present study, we are not able to draw firm conclusions of the magnitude of the problem.

\section{Thermal experience}

Temperature is fundamental to the ecology and physiology of fish because it controls vital processes
(Graham \& Harrod 2009). From September to March, the total thermal niche ranged from about 0 to $4.2^{\circ} \mathrm{C}$; this niche was narrower inside the icefjord $\left(0.6-3.0^{\circ} \mathrm{C}\right)$, which may indicate a more stable thermal environment than in Disko Bay, or that Greenland halibut traced to the icefjord rarely occupied depths below $200 \mathrm{~m}$. Overall, our results document a broad thermal niche occupied by a local population. In comparison, conspecifics in Cumberland Sound experienced a thermal niche of merely $1.4^{\circ} \mathrm{C}$ during periods of up to $300 \mathrm{~d}$ (Peklova et al. 2012). During summer months (June to August), fish in Disko Bay may experience temperatures of up to $10^{\circ} \mathrm{C}$ in the upper $50 \mathrm{~m}$ of the water column, with deeper waters being considerably cooler (Hansen et al. 2012). Tagging experiments during summer months could reveal whether the fish voluntarily expose themselves to such high temperatures.

Interestingly, in 2002, for which we have data from the first, third, and fourth quarters for both areas, Greenland halibut always experienced warmer waters in Disko Bay as compared to inside the icefjord; this was true both when looking at areaspecific averages for each quarter and when comparing overlapping depth-dependent temperatures. The cooler environment beneath the Jakobshavn Isbræ outlet glacier is likely due to bottom melting of the ice tongue (Holland et al. 2008, Motyka et al. 2011), which is also supported by the present observations of cooler temperatures at depths closest to the ice. It remains unclear whether migration into the icefjord is an outcome of selection of a cooler environment during these winter months, and if so, what the physiological significance may be.

Using Greenland halibut as a 'living measuring tool' we present, for the first time, temperatures beneath the Jakobshavn Isbræ, one of the largest outlet glaciers in the world. We document a positive relationship between temperature and depth down to approximately $600 \mathrm{~m}$, whereafter temperatures remain relatively stable. Using airborne expendable CTD probes, Holland et al. (2008) provided a single summer temperature profile taken at a northern branch approximately halfway into the Jakobshavn Isbræ, just beside the edge of the icesheet. Except for the upper $50 \mathrm{~m}$, this thermal profile also showed a positive correlation with depth, down to $500 \mathrm{~m}$. Notably, for the fourth quarter of the year for which data from all tagging years $(2001,2002$, and 2003) were available, we documented a clear between-year variation in temperatures beneath the icesheet. 


\section{Recapture rates and time}

The total recapture rate in present study $(6 \%)$ is comparable to 2 recent and similar studies (same species and the same type of tags) reporting $5 \%$ and $8 \%$ recapture rates (Vollen \& Albert 2008, Albert et al. 2011), but the number of days at sea was much higher for some of the tagged fish in these previous studies. In our study, all reported recaptures occurred within 6 mo after tagging. The lack of later recaptures could be due to tag shedding, tagging or natural mortality, or a combination of these. We feel that tagging mortality in this study is comparable to other studies using these types of tags, and the relatively narrow distribution of tag recaptures over time is most likely a result of high local fishing pressure.

\section{CONCLUSIONS}

In summary, we showed that recaptured Greenland halibut undertook seasonal migrations into the deep waters of the Ilulissat Icefjord. Furthermore, we were able to identify vertical activity, either movement in the water column or along the continental slope. These results confirm earlier observations on the behavior of Greenland halibut (Vollen \& Albert 2008, Albert et al. 2011), but the factor(s) that explain the seasonal migration into the icefjord and the pronounced vertical activity remain uncertain. Finally, our data revealed that during winter months, Greenland halibut experienced a thermal range of about $4.2^{\circ} \mathrm{C}$, encountering warmer waters in Disko Bay compared to inside the icefjord, irrespective of quarter of the year.

Acknowledgements. A grant from The Commission for Scientific Research in Greenland (grant number 10-079455) supported this work. Thanks to C. Gladish for providing the bathymetry map. We also thank 2 anonymous referees for their relevant comments and suggestions for changes, which have greatly improved the manuscript.

\section{LITERATURE CITED}

Albert OT, Lambert Y, Vollen T, Freitas C, Heggenbakken L (2011) Distinguishing pelagic and demersal swimming of deepwater flatfish by recording of body angles. In: McKenzie J, Parsons B, Seitz A, Kopf RK, Mesa M, Phelps Q (eds) Advances in fish tagging and marking technology. Am Fish Soc Symp 76, Bethesda, MD, p 507-528

Axelsson M, Fritsche R (1991) Effects of exercise, hypoxia and feeding on the gastrointestinal blood flow in the Atlantic cod Gadus morhua. J Exp Biol 158:181-198
Behrens JW, Axelsson M, Neuenfeldt S, Seth H (2012) Effects of hypoxic exposure during feeding on SDA and postprandial cardiovascular physiology in the Atlantic cod, Gadus morhua. PLoS ONE 7:e46227

Boje J (2002) Intermingling and seasonal migrations of Greenland halibut (Reinhardtius hippoglossoides) populations determined from tagging studies. Fish Bull 100: 414-422

Bowering WR, Nedreaas KH (2000) A comparison of Greenland halibut (Reinhardtius hippoglossoides (Walbaum)) fisheries and distribution in the Northwest and Northeast Atlantic. Sarsia 85:61-76

Broell F, Noda $\mathrm{T}$, Wright $\mathrm{S}$, Domenici P, Steffensen JF, Auclair JP, Taggart CT (2013) Accelerometer tags: detecting and identifying activities in fish and the effect of sampling frequency. J Exp Biol 216:1255-1264

Buch E (1990) A monograph on the physical environment of Greenland waters. DMI scientific report 00-12, Copenhagen

$>$ de Groot SJ (1970) Some notes on an ambivalent behaviour of the Greenland halibut Reinhardtius hippoglossoides (Walb.) Pisces: Pleuronectiformes. J Fish Biol 2:275-279

> Duthie GG (1982) The respiratory metabolism of temperature adapted flatfish at rest and during swimming activity and the use of anaerobic metabolism at moderate swimming speeds. J Exp Biol 97:359-373

Godø OR, Michalsen K (2000) Migratory behavior of northeast Arctic cod, studied by use of data storage tags. Fish Res 48:127-140

> Graham CT, Harrod C (2009) Implications of climate change for the fishes of the British Isles. J Fish Biol 74:1143-1205

> Gundersen AC, Kennedy J, Woll A, Boje J (2013) Identifying potential Greenland halibut spawning areas and nursery grounds off east and south-western Greenland and its management implications. J Sea Res 75:110-117

- Hansen MO, Nielsen TG, Stedmon CA, Munk P (2012) Oceanographic regime shift during 1997 in Disko Bay, western Greenland. Limnol Oceanogr 57:634-644

Holland DM, Thomas RH, de Young B, Ribergaard $\mathrm{MH}_{\text {, }}$ Lyberth B (2008) Acceleration of Jakobshavn Isbræ triggered by warm subsurface ocean waters. Nat Geosci 1:659-664

> Hunter E, Metcalfe JD, Reynolds JD (2003) Migration route and spawning area fidelity by North Sea plaice. Proc R Soc Lond B Biol Sci 270:2097-2103

Hunter E, Metcalfe JD, Holford BH, Arnold GP (2004) Geolocation of free-ranging fish on the European continental shelf as determined from environmental variables. II. Reconstruction of plaice ground tracks. Mar Biol 144: 787-798

> Jørgensen OA (1997) Pelagic occurrence of Greenland halibut, Reinhardtius hippoglossoides (Walbaum), in West Greenland waters. J Northwest Atl Fish Sci 21:39-50

Kawabe R, Nashimoto K, Hiraishi T, Naito Y, Sato K (2003) A new device for monitoring the activity of freely swimming flatfish, Japanese flounder Paralichthys olivaceus. Fish Sci 69:3-10

Kawabe R, Naito Y, Sato K, Miyashita K, Yamashita N (2004) Direct measurement of the swimming speed, tailbeat, and body angle of Japanese flounder (Paralichthys olivaceus). ICES J Mar Sci 61:1080-1087

- Makiguchi Y, Kuramochi K, Iwane S, Kojima T, Naito Y (2013) Take-off performance of flying fish Cypselurus heterurus doederleini measured with miniature acceleration data loggers. Aquat Biol 18:105-111 
Metcalfe JD, Arnold GP, McDowall PW (2002) Migration. In: Hart PJB, Reynolds JD (eds) Handbook of fish biology and fisheries, Vol 1. Fish biology. Blackwell Publishing, Oxford, p 175-199

Milligan CL, Hooke GB, Johnson C (2000) Sustained swimming at low velocity following a bout of exhaustive exercise enhances metabolic recovery in rainbow trout. J Exp Biol 203:921-926

Morgan MJ, Bowering WR, Gundersen AC, Høines A, Smirnov O, Morin B, Hjörleifsson E (2003) A comparison of the maturation of Greenland halibut (Reinhardtius hippoglossoides) from populations throughout the North Atlantic. J Northwest Atl Fish Sci 31:99-112

Motyka R, Truffer M, Fahnestock M, Mortensen J, Rysgaard S, Howat I (2011) Submarine melting of the 1985 Jakobshavn Isbræ floating tongue and the triggering of the current retreat. J Geophys Res 116:F01007, doi:10.1029/ 2009JF001632

Nygaard R, Boje J (2011) Standardized logbooks from the inshore longline fishery on Greenland halibut in the inshore part of Div. 1A. NAFO SCR 11/43 Serial No. N5928. Northwest Atlantic Fisheries Organization, Dartmouth

Nygaard R, Boje J (2013) Updated indices for the Greenland Halibut Stock Component in NAFO Division 1A Inshore. NAFO SCR 13/48. Northwest Atlantic Fisheries Organization, Dartmouth

Peklova I, Hussey NE, Hedges KJ, Treble MA, Fisk AT (2012) Depth and temperature preferences of the deepwater flatfish Greenland halibut Reinhardtius hippoglossoides in an Arctic marine ecosystem. Mar Ecol Prog Ser 467:193-205

Rayner NA, Parker DE, Horton EB, Folland CK and others (2003) Global analyses of sea surface temperature, sea

Editorial responsibility: Konstantinos Stergiou, Thessaloniki, Greece ice, and night marine air temperature since the late nineteenth century. J Geophys Res 108:4407, doi:10.1029/ 2002JD002670

Riget F, Boje J (1987) Distribution and abundance of young Greenland halibut (Reinhardtius hippoglossoides Walb.) in West Greenland waters. NAFO Sci Counc Stud 12: $7-12$

Schick RS, Loarie SR, Colchero F, Best BD and others (2008) Understanding movement data and movement processes: current and emerging directions. Ecol Lett 11: 1338-1350

Schumann K, Völker D, Weinrebe W (2012) Acoustic mapping of the Ilulissat Ice Fjord mouth, West Greenland. Quat Sci Rev 40:78-88

Serreze MC, Walsh JE, Chapin FS, Osterkamp T and others (2000) Observational evidence of recent change in the northern high-latitude environment. Clim Change 46: $159-207$

Smidt E (1969) The Greenland halibut, Reinhardtius hippoglossoides (Walb.), biology and exploitation in Greenland waters. Medd Dan Fisk Havunders 6:79-148

Solmundsson J (2007) Trophic ecology of Greenland halibut (Reinhardtius hippoglossoides) on the Icelandic continental shelf and slope. Mar Biol Res 3:231-242

Vollen T, Albert OT (2008) Pelagic behavior of adult Greenland halibut (Reinhardtius hippoglossoides). Fish Bull 106:457-470

Weidick A, Bennike O (2007) Quaternary glaciation history and glaciology of Jakobshavn Isbræ and the Disko Bugt region, West Greenland: a review. Geol Surv Den Greenl Bull 14:1-78

> West GJ, Stevens JD (2001) Archival tagging of school shark, Galeorhinus galeus, in Australia: initial results. Environ Biol Fishes 60:283-298

Submitted: October 7, 2013; Accepted: May 19, 2014 Proofs received from author(s): July 18, 2014 